\title{
The Development of Mobile Application Based Customer Service System in Bank Sampah Malang
}

\author{
Nur Hayatin ${ }^{* 1}$, Bayu Mavindo ${ }^{2}$, Eko Budi Cahyono ${ }^{3}$ \\ 1,2,3 Universitas Muhammadiyah Malang \\ noorhayatin@umm.ac.id ${ }^{* 1}$, master.mavindo@gmail.com², ebcahyono@yahoo.com ${ }^{3}$
}

\begin{abstract}
Malang Waste Bank, or commonly called Bank Sampah Malang (BSM), is a legal entity of incorporated cooperatives built by the Malang municipal government serving as a container of waste management, especially dry waste. During this time, the customer service process conducted in BSM has been not optimal, especially its online service. Some services have been accessible online through website but the information is limited only to the list of prices and types of waste received by BSM. While other necessary information needed by the customers such as balance checking, garbage collection schedule checking, and information about the types of saving managed by BSM has not been covered by the existing online system yet. This research has built an online customer service system based on mobile applications and SMS gateways for BSM. The purpose of the system is to facilitate the customers of BSM to obtain information about the garbage bank, especially for customers having high mobility. Interviews and observation are used as the method of the analysis of the system requirements. Meanwhile, the applications such as MySQL database, Web service, PHP Codelgniter, SMS Gateway and Android as a language programming are used to develop the system. This system integrates android applications with web based applications by using web service. This system is made so that customers get better service. Evaluation results show the system that has been built has been successfully tested.
\end{abstract}

Keywords: Application, Bank Sampah Malang, Customer Service, Mobile

\section{Introduction}

Nowadays, waste processing draws a great concern in modern society. Based on the report of "Indonesian Waste Statistics" in 2008, the total volume of waste in Indonesia reaches more than 43 million each year [1]. There are a lot of ways to implement waste processing. Moreover, many institutions facilitating the citizens in term of processing the waste have been established. Malang is one of the cities in Indonesia becoming a project leader in the waste processing. According to Letari (2014), the innovation program of waste processing in Malang is triggered by the citizens and the environmental activist [2][3]. One of the institutions having a role as the waste management is Bank Sampah (Garbage Bank). According to Suwerda (2012), Bank Sampah is a place where the service activities to the waste depositor/saver are carried out by tellers [4].

Bank Sampah Malang (BSM) is a legal entity of incorporated cooperative built by the municipal government of Malang serving a role as a forum for coaching, training, and assisting the citizens in waste processing, as well as purchasing and marketing the products of the waste processing [5]. Bank Sampah has a unique transaction system incorporated the transaction process covering buying and selling transaction of waste with money. In the transaction, there are two processes; the deposit process and the estimation process based on the market price. Those transactions are the main operations of Bank Sampah. In order to support the process, Bank Sampah Malang develops an application to simplify data management and to help BSM's administrators.

Bank Sampah Malang is one of the institutions which has already applied a system of management information on its administration and service. This system is imperative in order to support BSM due to providing quality customer service greatly affecting the customer loyalty [6]. A research by Masruroh (2015) related to Bank Sampah application shows that the application can assist the administrators in calculating the transaction and managing the customer data. In addition, Bank Sampah application is also able to minimize the transaction errors and can be used for data storage in more organizing and centralizing way. Furthermore, it can simplify the

Hayatin, N., Mavindo, B., \& Cahyono, E. (2017). The Development of Mobile Application Based Customer Service System in Bank Sampah Malang. Kinetik : Game Technology, Information System, Computer Network, Computing, Electronics, and Control, 2(4). doi:http://dx.doi.org/10.22219/kinetik.v2i4.266

Paper submitted on July 11, 2017; Revision on August 17, 2017; Received August 28, 2017 
delivery of Bank Sampah reports [7][8]. During this time, the customer service process that has been done in BSM is not optimal, especially the online services. The existing service system established on the web running on the internal network can only be operated by admins and staff of the institution. Some services have been accessible online through a website but the information is limited only to the list of prices and types of waste received by BSM. However, the other important information, exemplified by balance checking, garbage price, and garbage collection schedule, is not yet covered by the existing online system.

This research has built an online mobile app-based customer service system. The application which has been built is an improvement and development from the latest version of service system in BSM. The developed mobile app offers online customer service system to help the customers to obtain specific information related to Bank Sampah via an android smart phone. By utilizing this application, customers may access various online services such as balance information, waste price information, service requests to pickup waste offered to be sold, and confirmation and complaint services due to existing problems related to pickup services. In addition, this application is also developed in order to help garbage hauler drivers in obtaining schedule and location of waste collection. By developing this system, it could increase the customer service of BSM into a better service, being more practical and simple. This application can additionally facilitate those customers with high mobility to obtain the information needed wherever and whenever necessary. Furthermore, it may help the employees of BSM especially the garbage hauler drivers in doing their jobs.

\section{Research Method}

The method used in this research is system design because the research that has been done is a qualitative research developing a software. The design stages of mobile app customer service system of Bank Sampah are as follows:

\subsection{Design of Mobile App Architecture}

The customer service mobile application of Bank Sampah is an android application that can be used by users through a smart phone connected to the internet. The users of this application are divided into two, namely user and admin. The user group consists of customers and drivers. The application for the admin was developed by using web based in the form of clientserver. Hence, the developed system can be integrated with the existing application [9].

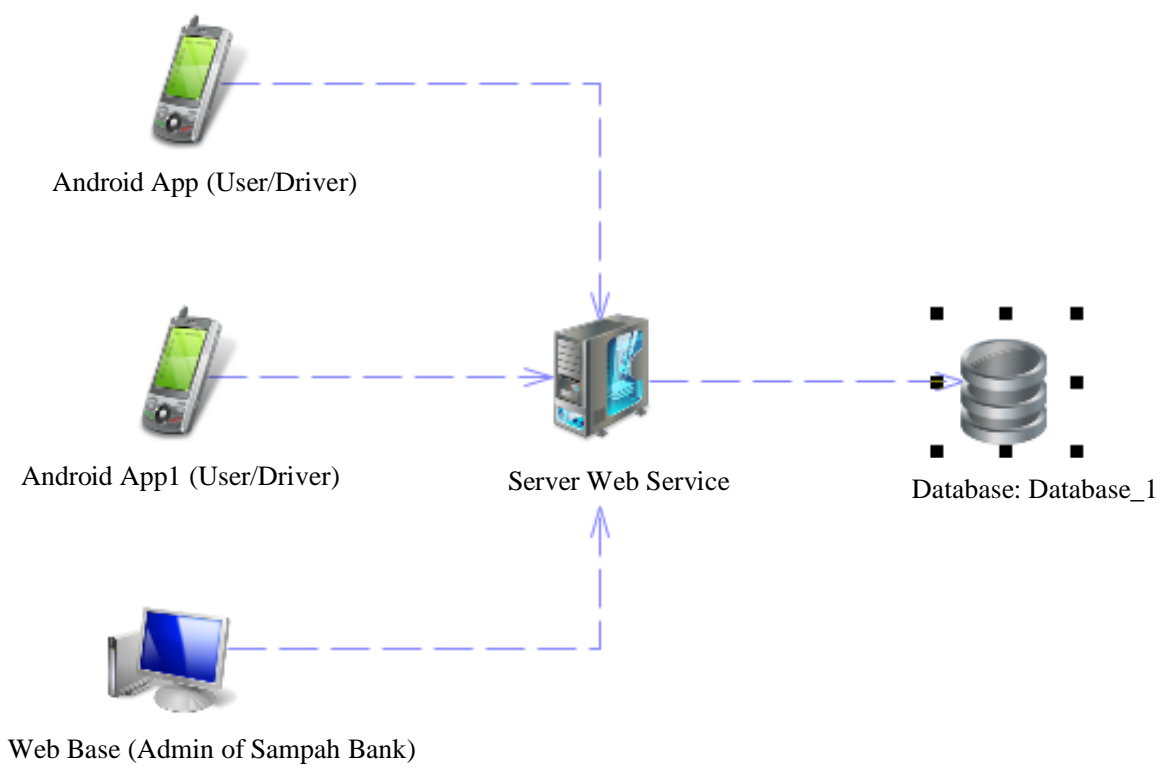

Figure 1. The Architecture of Customer Service Mobile App of Bank Sampah

The admin can access other functions such as add, edit, and delete events. Meanwhile, the android application was developed for the users. A general overview of the system architecture of customer service mobile app of BSM using the web service is illustrated in Figure

KINETIK Vol. 2, No. 4, November 2017: 291-298 
1. The mobile app which was built has several features including balance information, garbage price information and trash pickup services. The mobile app used was web service support with RESTful being able to access the functions of web service which was provided by the server.

As depicted in Figure 1, the architecture of customer service system was built from two applications namely: mobile app for users (customers and drivers) and web-based management application for admin. Both of these applications access the waste data bank from a server. The data on the server will be accessed by the client application. The relationship between client and server is bridged by web service file in certain format. Therefore, the access to the data base will be handled through an intermediary called web services. The role of web services will facilitate the distribution as well as the integration between these two applications. Web services are employed to provide services (in the form of information) to both systems, so that the two systems can interact with the service which was provided by the web.

\subsection{The Design of Use Case Diagram}

The design of customer service mobile app system in BSM is represented by use case diagram. The use case diagram for this application is divided into two actors: for users and for administrators. Use case diagram for user is illustrated by Figure 2. Meanwhile, Figure 3 depicts the use case diagram for admins.

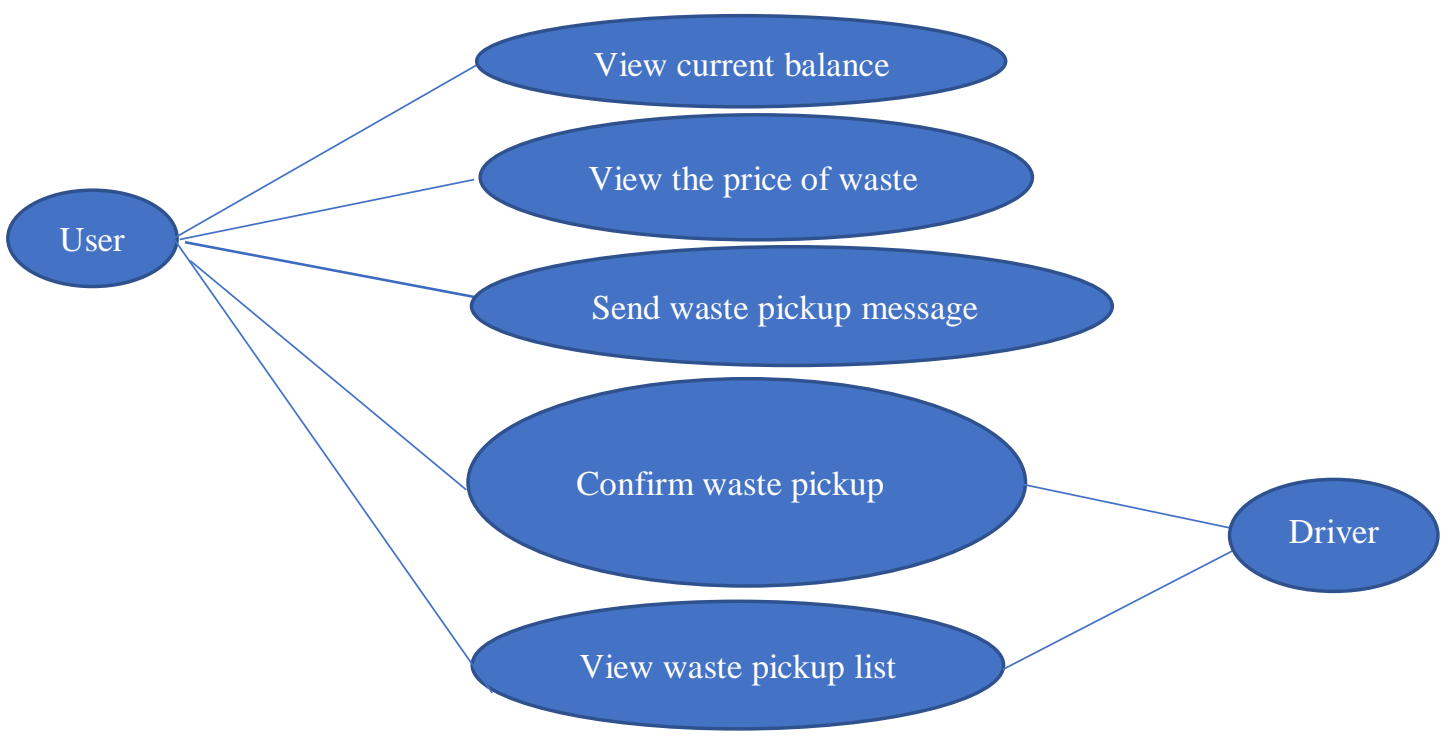

Figure 2. Use Case Diagram for Customers and Drivers

Figure 2 presents two actors getting involved in these accesses, customers and drivers. The customers can read the account number information, name, address and last balance. In addition, customers can also view waste code information, name, type, unit of purchase, and price of saved and direct waste. Customers may make an order by choosing from the menu message retrieval. Retrieval messages can be executed by filling in the destination address and the weight of waste. Furthermore, customers and drivers can confirm by selecting the fetch list menu. Confirmation can be completed by pressing the confirmation button. Customers and drivers can also view the fetch list as well as check the fetch status on the fetch list.

The costumer data management such as adding, updating or deleting data of the customers are some of the commands that can be done by administrators, illustrated by Figure 3. Data related to customer information includes the account number, customer name, address, mobile number, and current balance. Administrators can also perform waste data management function such as adding, changing or deleting waste related data. The waste data includes waste id, name, type, unit, direct price, and saved price. In addition, administrators can also perform driver management functions such as adding, modifying or deleting driver data. 


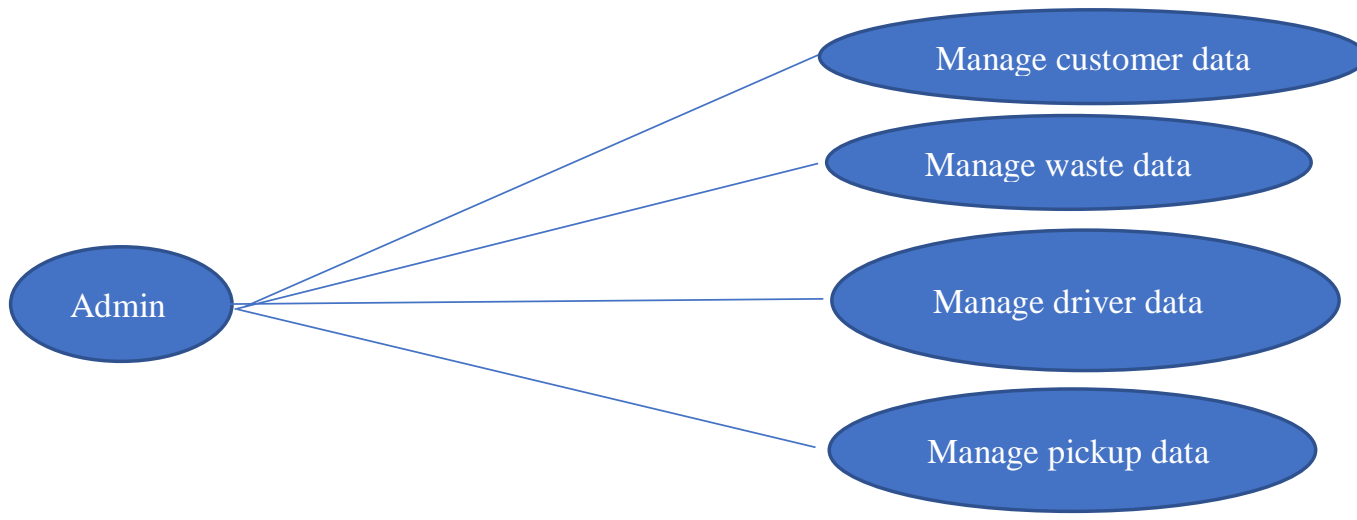

Figure 3. Use Case Diagram for Admin

\subsection{Design of Database}

The detail database of mobile app of BSM in physical form is described in the form of PDM (Physical Data Model). The PDM presents the correct data storage structure in the database used in the application. The picture of PDM can be seen in Figure 4.

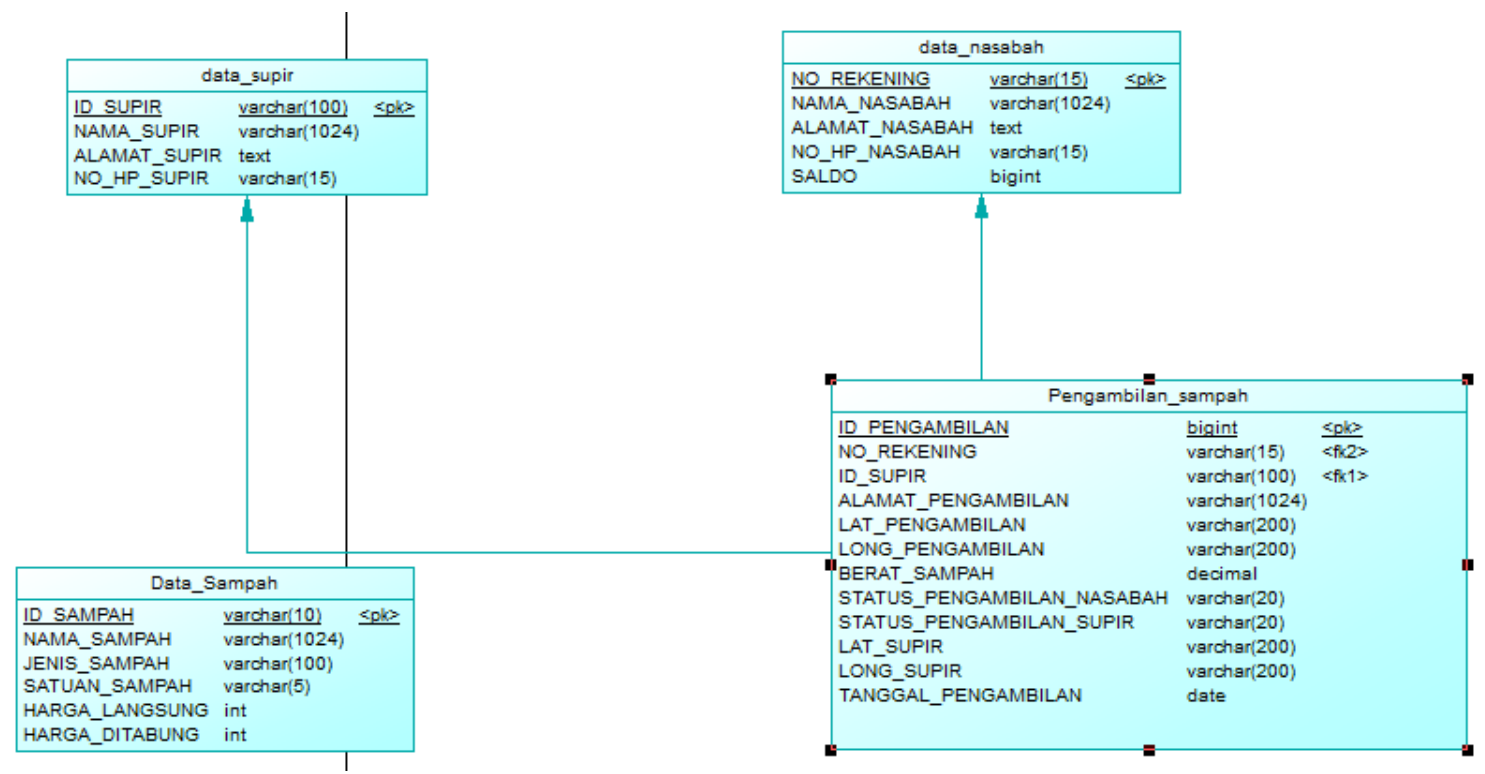

Figure 4. PDM Database of BSM Mobile Application

Figure 4 presents the tables which are used in BSM customer service app. Those table consist of: (1) data_nasabah or customer data table. It is used to store the customer data that can access customer service application. The field of data nasabah is account number, name, address, contact number, and current balance; (2) data_sopir or driver data. This data is used to store driver data that can access customer service application; (3) pengambilan_sampah or waste pickup data. This data is used to store waste pickup data that can access customer service application; and (4) data_sampah. This data is used to store waste data, consisting of id, name, type, and price.

\subsection{Design of Class Diagram}

The class diagram is used to display classes or packages within the system and the existing inter-class relationships in BSM mobile app. The class data retrieval is related to many classes including customer data classes, waste, driver, and waste pickup. The pickup data class becomes essential because this class contains important attributes of Bank Sampah 
management system. In other words, this class is utilized as a liaison with other classes. The class diagram for BSM mobile app customer service can be seen in Figure 5.

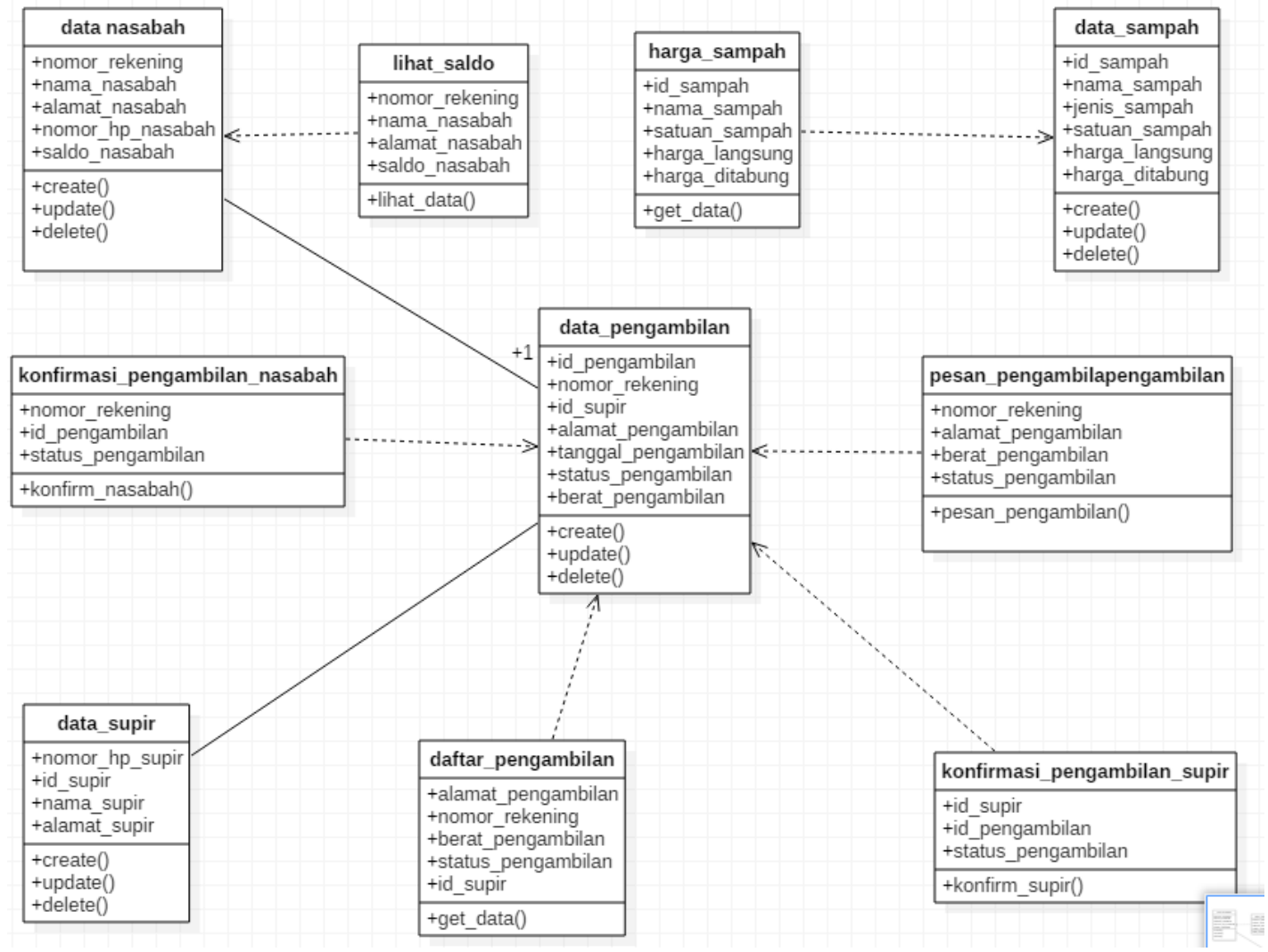

Figure 5. The Class Diagram of Mobile App of Bank Sampah Malang

\section{Results and Discussion}

The result of this research is a mobile application of BSM customer service along with the web-based application for admin. This research used Black-box testing method [10] to measure the success of the developed system. The Black-box testing method was employed to find out each existing feature or function in the application whether it can fully operate or not. In addition, the Black-box testing was able to discover improper or missing functions, interface errors, errors in the data structure or external database access, as well as performance, initialization, and termination errors. Moreover, the testing also checked the capability to functionally release the results as expected. The test was completed by running the application of Bank Sampah and then examined its output. The testing of customer service application was done by using test data in the form of a data and input from the users. The result of the test in this research can be seen in Table 1.

Based on the test result which was presented by Table 1, it can be seen that the system of BSM consumer service based on Android app can display current balance, waste price, and can deliver the waste pickup order from the customers. In addition, the feature of maps on Android also has been able to properly show maps as expected. According to the test results indicating that BSM mobile app based customer service system has been well functioned because all features have been run properly. The results also exhibit that the application has no syntax error and provides good results as expected.

The mobile application system of customer service can facilitate customers in getting information and also help BSM to provide customer service functions through smartphones. The process of waste deposit between the customers and the employees of Bank Sampah can be well organized with the registration and confirmation of waste collection through this application. The mobile app can provide convenience for customers and also to the Bank Sampah itself because it allows them to control the process of depositing and providing the convenience to Bank 
Sampah employees to provide better services for customers. The application of customer service especially Bank Sampah needs to develop in line with the times in order to adapt with the rapidly growing technology. The creation of library or framework for customer service application can be applied to facilitate in making the next application. The development of BSM customer service application only supports to view current balance and waste price information and also to request waste pickup. Furthermore, some features such as mobile transaction registration and pickup waste monitoring in web application-based admin can be added. It is suggested that BSM app has to add some applications for other mobile platforms such as BlackBerry, Windows Phone, and iPhone operating system.

Table 1. System Test Results Using Black Box Testing

\begin{tabular}{|c|c|c|c|c|}
\hline \multirow{2}{*}{ Features } & \multicolumn{4}{|c|}{ Cases and Test Results } \\
\hline & Data Input & Expected & Observation & Conclusion \\
\hline View Balance & $\begin{array}{l}\text { Show balance data } \\
\text { in accordance with } \\
\text { the customer } \\
\text { account number }\end{array}$ & $\begin{array}{l}\text { Display balance } \\
\text { data in accordance } \\
\text { with the customer } \\
\text { account number }\end{array}$ & $\begin{array}{l}\text { Display all data } \\
\text { as expected }\end{array}$ & Received \\
\hline $\begin{array}{c}\text { View Waste } \\
\text { Price }\end{array}$ & Show all waste data & $\begin{array}{c}\text { Display all waste } \\
\text { data in the table of } \\
\text { waste data }\end{array}$ & $\begin{array}{l}\text { Display all data } \\
\text { as expected }\end{array}$ & Received \\
\hline $\begin{array}{c}\text { Pickup } \\
\text { Messages }\end{array}$ & $\begin{array}{l}\text { Click the pickup } \\
\text { message button; } \\
\text { Input the address; } \\
\text { Click the booking } \\
\text { button. }\end{array}$ & $\begin{array}{c}\text { Display form of } \\
\text { additional pickup } \\
\text { data; } \\
\text { List all data in the } \\
\text { text box; } \\
\text { Store data in the } \\
\text { database }\end{array}$ & $\begin{array}{l}\text { Display form of } \\
\text { addition data; } \\
\text { Can fill the } \\
\text { input data as } \\
\text { expected; } \\
\text { Store data in } \\
\text { the database }\end{array}$ & Received \\
\hline Pickup List & $\begin{array}{l}\text { Show the pickup } \\
\text { data by date }\end{array}$ & $\begin{array}{l}\text { Display pickup data } \\
\text { by date }\end{array}$ & $\begin{array}{l}\text { Display all data } \\
\text { as expected }\end{array}$ & Received \\
\hline $\begin{array}{c}\text { Pickup } \\
\text { Confirmation }\end{array}$ & $\begin{array}{l}\text { Pick confirmation } \\
\text { button }\end{array}$ & $\begin{array}{c}\text { Show an updating } \\
\text { pickup status in } \\
\text { database }\end{array}$ & $\begin{array}{l}\text { Pickup data } \\
\text { successfully } \\
\text { updated }\end{array}$ & Received \\
\hline Pickup Maps & $\begin{array}{l}\text { Show the pickup } \\
\text { data by date }\end{array}$ & $\begin{array}{c}\text { Show pickup } \\
\text { location on the map } \\
\text { based on data }\end{array}$ & $\begin{array}{l}\text { Show all data } \\
\text { as expected }\end{array}$ & Received \\
\hline $\begin{array}{c}\text { Pick the } \\
\text { Pickup Data }\end{array}$ & $\begin{array}{l}\text { Pick the pickup } \\
\text { location }\end{array}$ & $\begin{array}{c}\text { Show the } \\
\text { navigation to the } \\
\text { pickup location }\end{array}$ & $\begin{array}{l}\text { Show the } \\
\text { navigation as } \\
\text { expected }\end{array}$ & Received \\
\hline
\end{tabular}

\section{Conclusion}

Based on the previous discussion, it can be concluded on several things as follows:

1. Mobile app-based customer service system of Bank Sampah Malang (BSM) can facilitate the customers to get the information about Bank Sampah and provide service functions to the customers through a smartphone. Moreover, this application also provides convenience to the customers and Bank Sampah to control the process of depositing as well as better services given by the employees to the customers.

2. BSM customer service mobile app has been well functioned because all existing features in the application run properly.

\section{References}

[1] Indonesia State Ministry of Environtment, "Indonesian Waste Disposal Statistics 2008," 2008.

[2] A. Lestari, "Innovative Program on Waste Management in Malang City," Public Administration Journal, Vol. 2, No. 3, Pp. 571-577, 2014.

[3] S. Arief, "Waste Management in Malang leading to Integrated Waste Management Based on Social Participation," Humanity Journal, Vol. 8, No. 2, 2013. 
[4] B. Suweda, "Waste Bank (Theoretical Study and Application)," Yogyakarta: Pustaka Rihama, 2012.

[5] D. K. Malang, "Waste Management in Malang," Malang: Sanitary and Landscape Gardening Agency of Malang. 2015.

[6] R. Saputro, "Analysis of Product Quality, Service Quality, and Customer Trust to Customer Loyarty," Universitas Diponegoro Semarang, 2010.

[7] S. Yustanti, M.I. ; Hermawan Sulistyanto, "Design of Waste Bank Web-Based System Information," Universitas Muhammadiyah Surakarta, 2017.

[8] I. Purwanto, "Design of System Information on Saving Transaction of Garut Waste Bank," Algorithm Journal STT Garut, Vol. 9, 2012.

[9] J. Predede, "Implementation of Web Service Composite (A Case Study on Tourism Application," ITENAS Bandung, 2013.

[10] B. Beizer, "Black-Box Testing: Techniques For Functional Testing of Software and Systems." John Wiley \& Sons, Inc., 1995. 
